\title{
The 2012 SAGE wait times program: Survey of Access to GastroEnterology in Canada
}

\author{
Desmond Leddin $\mathrm{MB}^{1}$, David Armstrong $\mathrm{MD}^{2}$, Mark Borgaonkar $\mathrm{MD}^{3}$, Ronald J Bridges $\mathrm{MD}^{4}$, \\ Carlo A Fallone MD ${ }^{5}$, Jennifer J Telford MPH MD ${ }^{6}$, Ying Chen MSc ${ }^{2}$, Palma Colacino7, Paul Sinclair MSc ${ }^{7}$
}

\begin{abstract}
D Leddin, D Armstrong, M Borgaonkar, et al. The 2012 SAGE wait times program: Survey of Access to GastroEnterology in Canada. Can J Gastroenterol 2013;27(2):83-89.
\end{abstract}

BACKGROUND: Periodically surveying wait times for specialist health services in Canada captures current data and enables comparisons with previous surveys to identify changes over time.

METHODS: During one week in April 2012, Canadian gastroenterologists were asked to complete a questionnaire (online or by fax) recording demographics, reason for referral, and dates of referral and specialist visits for at least 10 consecutive new patients (five consultations and five procedures) who had not been seen previously for the same indication. Wait times were determined for 18 indications and compared with those from similar surveys conducted in 2008 and 2005.

RESULTS: Data regarding adult patients were provided by 173 gastroenterologists for 1374 consultations, 540 procedures and 293 same-day consultations and procedures. Nationally, the median wait times were 92 days (95\% CI 85 days to 100 days) from referral to consultation, 55 days ( $95 \%$ CI 50 days to 61 days) from consultation to procedure and 155 days (95\% CI 142 days to 175 days) (total) from referral to procedure. Overall, wait times were longer in 2012 than in 2005 $(\mathrm{P}<0.05)$; the wait time to same-day consultation and procedure was shorter in 2012 than in 2008 ( 78 days versus 101 days; $\mathrm{P}<0.05)$, but continued to be longer than in $2005(\mathrm{P}<0.05)$. The total wait time remained longest for screening colonoscopy, increasing from 201 days in 2008 to 279 days in $2012(\mathrm{P}<0.05)$.

DISCUSSION: Wait times for gastroenterology services continue to exceed recommended targets, remain unchanged since 2008 and exceed wait times reported in 2005.

Key Words: Access; Audit; Canada; Endoscopy; Gastroenterology; Wait time

Deriodic surveys of wait times for specialist services provide importPant information on patients' current access to health care. Comparison with previous surveys also permits the evaluation of improvements attributable to interventions and the identification of areas in which further interventions may be necessary.

Since 2007, the Wait Time Alliance has published report cards pertaining to health care access in Canada. The report card for 2012, assessing data from 14 national medical organizations, including the Canadian Association of Gastroenterology (CAG), shows that wait times in many specialties have not improved over initial assessments (1).

In the effort to identify strategies to ensure that Canadians receive health care in a timely fashion, wait-time benchmarks have been established for many areas of medicine. The benchmarks for gastroenterology have remain unchanged since their development in 2005: emergency cases should be seen within $24 \mathrm{~h}$; urgent cases should be seen within two weeks; semi-urgent cases should be seen within two months; and routinely scheduled cases should be seen within six months (2).

\section{Le programme SAGE 2012 sur les temps d'attente : le sondage sur l'accès à la gastroentérologie au Canada}

HISTORIQUE : Un sondage périodique sur les temps d'attente pour accéder à des services de santé spécialisés au Canada permet de saisir des données à jour et de les comparer à des sondages antérieurs afin de déterminer les modifications au fil du temps.

MÉTHODOLOGIE : Pendant une semaine en avril 2012, des gastroentérologues canadiens ont été invités à répondre à un questionnaire (par Internet ou par télécopieur) qui incluait des données démographiques, la raison de l'aiguillage, les dates d'aiguillage et de visites à un spécialiste au sujet d'au moins dix nouveaux patients consécutifs (cinq consultations et cinq interventions) qui n'avaient pas encore consulté pour la même indication. Les chercheurs ont déterminé les temps d'attente à l'égard de 18 indications et les ont comparés à ceux de sondages similaires menés en 2008 et en 2005.

RÉSULTATS : Les données sur les patients adultes proviennent de 173 gastroentérologues et de 1374 consultations, de 540 interventions et de 293 consultations suivies d'une intervention le même jour. Sur la scène nationale, le temps d'attente médian était de 92 jours (95\% IC 85 jours à 100 jours) entre l'aiguillage et la consultation, de 55 jours (95\% IC 50 jours à 61 jours) entre la consultation et l'intervention et d'un total de 155 jours ( $95 \%$ IC 142 jours à 175 jours) entre l'aiguillage et l'intervention. Dans l'ensemble, les temps d'attente étaient plus longs en 2012 qu'en $2005(\mathrm{P}<0,05)$, tandis que le temps d'attente pour une consultation suivie d'une intervention le même jour était plus court en 2012 qu'en 2008 (78 jours plutôt que 101 jours; $\mathrm{P}<0,05$ ), mais demeurait plus long qu'en $2005(\mathrm{P}<0,05)$. Le temps d'attente total le plus long s'associait à la coloscopie de dépistage, qui est passée de 201 jours en 2008 à 279 jours en $2012(\mathrm{P}<0,05)$.

EXPOSÉ : Les temps d'attente en gastroentérologie continuent d'être supérieurs aux cibles recommandées. Ils n'ont pas changé depuis 2008 et sont plus longs que ceux déclarés en 2005.

There have been two previous audits to assess wait times for patients with digestive diseases. The 2005 Practice Audit in GastroEnterology (PAGE) (3) revealed that wait times in practice often exceeded the recommended benchmarks $(2,4)$, and the 2008 Survey of Access to GastroEnterology (SAGE), revealed again that wait times exceeded benchmarks and that they had, in fact, lengthened significantly since the PAGE study conducted three years previously (5).

Many factors may affect patients' wait times for gastroenterology services including the number of gastroenterologists and other endoscopists, colorectal cancer screening programs, resource availability, patient expectations, changes in technology and care pathways, and changes in patient load due to population growth or aging. In 2007, it was estimated that there were 550 gastroenterologists in Canada, corresponding to 1.83 per 100,000 population (6). As the population ages, the likelihood of gastrointestinal diseases and the need for appropriate interventions, as well as the adoption of colorectal cancer screening programs, will substantially increase the demand for colonoscopy and, thus, decrease the availability of consultation and endoscopy resources for other conditions.

${ }^{1}$ Dalhousie University, Halifax, Nova Scotia; ${ }^{2}$ McMaster University, Hamilton, Ontario; ${ }^{3}$ Memorial University of Newfoundland, Newfoundland and

Labrador; ${ }^{4}$ University of Calgary, Calgary, Alberta; ${ }^{5} \mathrm{McGill}$ University, Montreal, Quebec; ${ }^{6}$ University of British Columbia, Vancouver, British

Columbia; ${ }^{7}$ Canadian Association of Gastroenterology, Oakville, Ontario

Correspondence: Dr Desmond Leddin, Dalhousie University, Division of Gastroenterology, Room 912, Victoria Building, Victoria General Hospital Site,

1278 Tower Road, Halifax, Nova Scotia B3H 2Y9. Telephone 902-473-7833, fax 902-473-4406, e-mail desmond.leddin@dal.ca

Received for publication November 8, 2012. Accepted November 10, 2012 


\section{TABLE 1}

SAGE clinician demographic survey

\begin{tabular}{|c|c|}
\hline 1. Physician sex: & $\begin{array}{l}\square \text { Male } \\
\square \text { Female }\end{array}$ \\
\hline \multicolumn{2}{|c|}{$\begin{array}{l}\text { 2. Postal code of the institution where you do the majority of your } \\
\text { procedures (endoscopy, liver biopsies, etc): }\end{array}$} \\
\hline 3. Affiliation: & $\begin{array}{l}\square \text { Predominantly teaching hospital } \\
\text { based } \\
\square \text { Predominantly community-based with } \\
\text { hospital privileges } \\
\square \text { Predominantly community-based } \\
\text { without hospital privileges }\end{array}$ \\
\hline 4. Your practice is: & $\begin{array}{l}\square \text { Luminal } \\
\square \text { Liver } \\
\square \text { Both luminal and liver }\end{array}$ \\
\hline 5. Your practice is: & $\begin{array}{l}\square \text { Adult } \\
\square \text { Pediatric }\end{array}$ \\
\hline 6. Your practice is: & $\begin{array}{l}\square \text { Full-time } \\
\square \text { Part-time: If part-time, what } \\
\text { percentage of time do you work? }\end{array}$ \\
\hline \multicolumn{2}{|c|}{$\begin{array}{l}\text { 7. What percentage of your work week is spent in clinical care? Please } \\
\text { round to the nearest } 10 \%\end{array}$} \\
\hline $\begin{array}{l}\text { 8. Have you limited new patient } \\
\text { referrals because of the } \\
\text { length of your wait list? }\end{array}$ & $\begin{array}{l}\square \text { No } \\
\square \text { Yes }\end{array}$ \\
\hline $\begin{array}{l}\text { 9. How long have you been in } \\
\text { Gl practice?* }\end{array}$ & $\begin{array}{l}\square<5 \\
\square 5-10 y \\
\square 10-20 y \\
\square 20-30 y \\
\square 30+y\end{array}$ \\
\hline $\begin{array}{l}\text { 10. How satisfied are you with } \\
\text { your current wait times?* }\end{array}$ & $\begin{array}{l}\square \text { Not at all satisfied } \\
\square \text { Slightly satisfied } \\
\square \text { Somewhat satisfied } \\
\square \text { Very satisfied } \\
\square \text { Extremely satisfied }\end{array}$ \\
\hline $\begin{array}{l}\text { *New for SAGE 2012. GI Gastrc } \\
\text { GastroEnterology; y Years }\end{array}$ & oenterology; SAGE Survey of Access \\
\hline
\end{tabular}

The aim of the present study was to survey and report the national wait times for specialist gastroenterology care in 2012, and to compare these with the wait times reported in 2005 (3) and 2008 (5).

\section{METHODS}

The methodology used in the present study was similar to that used for the previous audit, SAGE 2008 (5). The CAG National Office handled all administrative aspects of the program. The data collection strategy and analysis was supervised by the SAGE advisory group (DL, $\mathrm{DA}, \mathrm{RB}, \mathrm{CF}, \mathrm{JT}, \mathrm{MB}, \mathrm{PC}$ and PS), who provided expertise in gastroenterology care.

\section{Participants}

Canadian gastroenterologists and internists specializing in gastroenterology were informed of SAGE 2012 through mailed announcements to CAG members and provincial gastroenterology organizations, advertisements in monthly e-newsletters, Canadian Journal of Gastroenterology notices and the CAG website. Gastroenterologists or internists who perform endoscopy who were not CAG members were identified through the Canadian Medical Directory and also invited to participate.

Interested physicians were directed, through the CAG website, to contact the CAG National Office via e-mail (sage@cag-acg.org), a toll-free number or fax to advise CAG as to how they would prefer to complete the survey (online or on paper). Depending on their expressed preference, registered participants received an e-mail containing the URL to the encrypted survey or paper forms to be completed and returned via fax before the survey.

\begin{tabular}{|lc|}
\hline TABLE 2 & \\
SAGE patient information survey \\
\hline 1. Patient's age: & $\square-18$ years \\
& $19-50$ years \\
& $\square 1$ years or older \\
\hline 2. Primary indication (associated numeric code): \\
\begin{tabular}{ll} 
(if codes 1-18 do not apply, write in the primary indication) \\
Esophagus and stomach & Abdomen/large intestine \\
$\square$ Severe or rapidly progressing & $\square$ Chronic abdominal pain (10) \\
dysphagia or odynophagia (1) & $\square$ Clinical features of significant \\
$\square$ Stable dysphagia that is not severe (2) & active IBD (11) \\
$\square$ Chronic GERD referred for screening & $\square$ Chronic diarrhea or chronic \\
endoscopy (3) & constipation (12) \\
$\square$ Poorly-controlled reflux/dyspepsia, NO & $\square$ New-onset change in bowel \\
alarm symptoms (4) & habit (13) \\
$\square$ Dyspepsia WITH alarm symptoms (5) & $\square$ Bright red rectal bleeding (14) \\
Small intestines & $\square$ Documented iron deficiency \\
$\square$ Confirmation of celiac disease & anemia (15) \\
antibody test (6) & $\square$ Fecal occult blood test positive \\
Liver & (16) \\
$\square$ Painless obstructive acute jaundice (7) & $\square$ Screening colonoscopy (17) \\
$\square$ Persistent (>6 months) abnormal liver & Miscellaneous \\
function tests (8) & $\square$ Cancer likely based on imaging \\
$\square$ Chronic viral hepatitis (9) & or physical exam (18) \\
& $\square$ Other (write in diagnosis) (19) \\
\hline 3. Date patient FIRST referred? & \\
\hline 4. Date of CONSULT? & \\
\hline 5. Date of PROCEDURE? & \\
\hline GERD Gastroesophageal reflux disease; IBD Inflammatory bowel disease; \\
SAGE Survey of Access to GastroEnterology
\end{tabular} \\
\hline
\end{tabular}

\section{Questionnaire}

With the exception of two additional demographic questions (number of years in practice and physicians' satisfaction with their current wait times), the SAGE 2012 survey was identical to SAGE 2008 (Tables 1 and 2). The questionnaire was available in English or French.

Participants provided personal demographic data (Table 1) and anonymized information on five consecutive clinic patients (consultations), and five consecutive endoscopy outpatients (Table 2) who had not been seen previously for the same indication. Patients who were seen for same-day consultation and procedure $(\mathrm{C} \& \mathrm{P})$ were included and analyzed separately.

Similar to the 2008 survey, the SAGE evaluated wait times relating to 18 selected nonurgent indications based on the Canadian consensus on medically acceptable wait times for digestive health care (2), as well as an 'other' write-in category. SAGE 2012 was conducted during the week of April 16 to 20, 2012; however, prospective participants who were unavailable during this week were able to register for data collection to occur during the weeks of April 9 to 13 or April 23 to 27, 2012. Electronic data were collected using a web-based platform (ECD Solutions, USA) while paper-based data collection forms were faxed directly to the CAG office.

Ethics review

In the present survey, no patient identifiers were collected, no patient participation or intervention was required, and aggregate results were presented such that no individual participating physician could be identified. The practice audit program was approved by a central ethics committee (Institutional Review Board, Aurora, Ontario, January 2012) and, if required, by a local ethics board.

\section{Data analysis}

Data analysis and statistical evaluation (SAS version 9.2, SAS Institute Inc, USA) were completed (YC) under the auspices of the Division of Gastroenterology, McMaster University, Hamilton, 
TABLE 3

Provincial distributions of physicians and patients included in the Survey of Access to GastroEnterology 2012

\begin{tabular}{|c|c|c|c|c|}
\hline Province/territory & $\begin{array}{l}\text { Population } \\
\text { Q2 2012, n }\end{array}$ & $\begin{array}{c}\text { Physicians, } \\
\text { n (\%) }\end{array}$ & $\begin{array}{c}\text { Patients, } \\
\text { n (\%) }\end{array}$ & $\begin{array}{c}\text { Patients/ } \\
100,000 \\
\text { population }\end{array}$ \\
\hline Canada & $34,755,634$ & $173(100)$ & $1899(100)$ & 5.5 \\
\hline British Columbia & $4,606,451$ & $22(12.7)$ & $304(16.0)$ & 6.6 \\
\hline Alberta & $3,847,119$ & $41(23.7)$ & 368 (19.4) & 9.6 \\
\hline Saskatchewan & $1,072,082$ & $2(1.2)$ & $47(2.5)$ & 4.4 \\
\hline Manitoba & $1,261,498$ & $11(6.4)$ & $126(6.6)$ & 10.0 \\
\hline Ontario & $13,472,438$ & $56(32.4)$ & $654(34.4)$ & 4.9 \\
\hline Quebec & $8,028,434$ & $24(13.9)$ & $221(11.6)$ & 2.8 \\
\hline New Brunswick & 755,381 & $4(2.3)$ & $43(2.3)$ & 5.7 \\
\hline Nova Scotia & 944,968 & $8(4.6)$ & $91(4.8)$ & 9.6 \\
\hline Prince Edward Island & 146,152 & $0(0)$ & $0(0)$ & 0.0 \\
\hline Newfoundland/Lab & 509,348 & $5(2.9)$ & $45(2.4)$ & 8.8 \\
\hline Nunavut/NWT/Yukon & 111,845 & $0(0)$ & $0(0)$ & 0.0 \\
\hline
\end{tabular}

Population data adapted from reference 18. Lab Labrador; NWT Northwest Territories; Q Quarter

Ontario. As in previous surveys $(3,5)$, wait time durations were defined as the following:

1. Wait time to consultation: The time the patient was first referred to the digestive health care provider until the consultation;

2. Wait time to procedure: The time the patient first consulted with the digestive health care provider until the completion of the digestive disease procedures; and

3. Total wait time: The time the patient was first referred to the digestive health care provider until completion of the procedure. Total wait time is available only for those patients who had both a C\&P.

4. Wait time to same-day C\&P: The time between the date of the initial referral to the digestive health care provider and the date on which both the C\&P were performed. Similar to the previous studies, data for same-day C\&P patients were analyzed separately.

Wait times are presented as medians with 95\% CIs, and statistical comparisons with data from the PAGE and SAGE 2008 surveys were performed using the Wilcoxon's rank-sum test with adjustment for multiple comparisons.

\section{RESULTS}

\section{Participants}

In April 2012, 173 gastroenterologists or internists practising gastroenterology in Canada participated in the one-week SAGE 2012 survey. The majority of participants were male $(n=139$ [80.3\%]) and were in full-time practice $(n=163$ [94.2\%]). More than one-half were affiliated with a teaching hospital $(56.1 \%[\mathrm{n}=97])$, with the remaining clinicians being community-based, with $(38.7 \%[\mathrm{n}=67])$ or without $(5.2 \%[n=9])$ hospital privileges. Most of the participant's practices specialized in both luminal and liver diseases $(53.8 \%$ [n=93]) or luminal diseases only $(39.9 \%[n=69])$; only $6.4 \%(n=11)$ specialized only in liver diseases. Almost two-thirds $(65.4 \%$ [n=113]) of participants indicated that they spend more than $70 \%$ of their work week engaged in clinical care and almost one-third $(n=54$ [31.2\%]) of the participants were limiting new patient referrals. Approximately $24 \%$ of participants indicated they had been in practice for fewer than five years, $16 \%$ for five to 10 years, $23 \%$ for 11 to 20 years, $24 \%$ for 21 to 30 years, and $13 \%$ for more than 30 years. When asked about their level of satisfaction with current wait times, most responded "not at all" $(42.2 \%)$, and only $4 \%$ and $6.4 \%$ responded "extremely" or "very" satisfied, respectively.
TABLE 4

Overall wait times in SAGE 2012, SAGE 2008 and PAGE 2005

\begin{tabular}{|c|c|c|c|c|}
\hline & \multicolumn{4}{|c|}{ Time, days, median $(95 \% \mathrm{Cl})$} \\
\hline & $\begin{array}{c}\text { To } \\
\text { consultation }\end{array}$ & $\begin{array}{c}\text { To } \\
\text { procedure }\end{array}$ & $\begin{array}{l}\text { Total } \\
\text { wait }\end{array}$ & $\begin{array}{l}\text { Same-day } \\
\text { consultation \& } \\
\text { procedure }\end{array}$ \\
\hline SAGE 2012 & $\begin{array}{c}92^{*}(85-100) \\
(n=1374)\end{array}$ & $\begin{array}{c}55^{*}(50-61) \\
(n=540)\end{array}$ & $\begin{array}{c}155^{*}(142-174) \\
(n=540)\end{array}$ & $\begin{array}{c}78^{* \dagger}(64-94) \\
(n=293)\end{array}$ \\
\hline SAGE 2008 & $\begin{array}{c}92^{*}(87-97) \\
(n=1824)\end{array}$ & $\begin{array}{c}50^{*}(45-55) \\
(n=741)\end{array}$ & $\begin{array}{c}155^{\star}(143-164) \\
(n=741)\end{array}$ & $\begin{array}{c}101^{*}(87-116) \\
(n=436)\end{array}$ \\
\hline PAGE 2005 & $\begin{array}{c}69(66-71) \\
(n=3965)\end{array}$ & $\begin{array}{c}37(31-43) \\
(n=846)\end{array}$ & $\begin{array}{c}127(116-140) \\
(n=846)\end{array}$ & $\begin{array}{c}55(48-62) \\
(n=852)\end{array}$ \\
\hline
\end{tabular}

${ }^{*} P<0.05$ versus $2005 ;{ }^{\dagger} P<0.05$ versus 2008. PAGE Practice Audit in GastroEnterology; SAGE Survey of Access to GastroEnterology

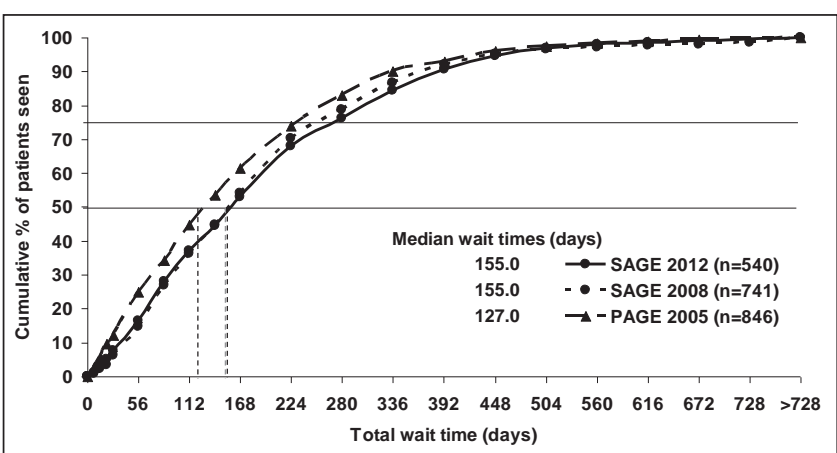

Figure 1) Comparison of national median total wait times across the three surveys. Median total wait times in 2012 and 2008 were significantly longer than in $2005(P<0.05)$. PAGE Practice Audit in GastroEnterology; SAGE Survey of Access to GastroEnterology

The distributions of participants and patients according to province are shown in Table 3. There were no participants from Prince Edward Island, the Yukon or Nunavut/Northwest Territories.

\section{Overall wait times}

Data regarding adult patients were collected for 1374 consultations, 540 procedures and 293 same-day C\&P. Most cases were reported in one of the 18 primary indication categories, with only 122 being classified as 'other' indications.

Nationally, the median wait time to consultation was 92 days (95\% CI 85 days to 100 days), wait time to procedure was 55 days (95\% CI 50 days to 61 days) and total wait time was 155 days (95\% CI 142 days to 175 days) (Table 4). The wait time to same-day C\&P in 2012 was shorter than in $2008(\mathrm{P}<0.05)$ but longer than in PAGE 2005 $(\mathrm{P}<0.05)$ (Table 4). Procedure, consultation and total wait times were significantly longer than those reported in $2005(\mathrm{P}<0.05)$, but did not differ significantly from those observed in 2008 (Table 4, Figure 1).

Provincially, there were few significant changes in wait times for 2012 compared with 2008 (Figure 2). Total wait times in 2012 were significantly longer in British Columbia and significantly shorter in Alberta compared with 2008; however, patient numbers in Alberta were small in 2012 ( $\mathrm{n}=51$ for total wait times). Total wait times were significantly longer for British Columbia, Quebec and Newfoundland in 2012 compared with 2005.

In 2012, wait times to consultation and same-day C\&P were both significantly longer in teaching hospital practices than in community-based practices ( 120 days versus 82 days; 119 days versus 64 days, respectively; $\mathrm{P}<0.05)$. Comparing 2012 with 2008, there was a significant increase in wait time to consultation in teaching hospital practices ( 112 days versus 99 days; $\mathrm{P}<0.05$ ) and a significant improvement in wait time to same-day $\mathrm{C} \& \mathrm{P}$ in community-based practices (63 days versus 87 days; $\mathrm{P}<0.05$ ). 


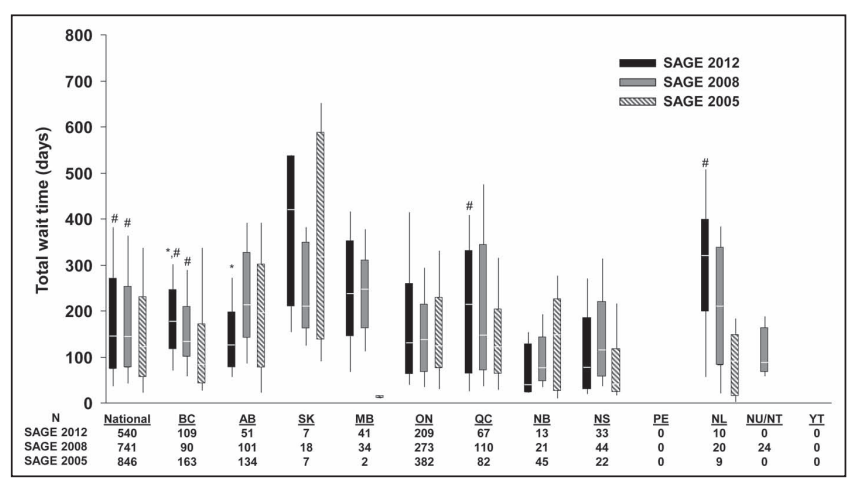

Figure 2) Box-and-whisker plot of total wait times according to province. Wilcoxon rank-sum test with multiple comparison adjustment. Box = median and 25 th to 75 th percentiles, whisker bar $=10$ th to 90 th percentiles. $* P<0.05$ versus 2008; ${ }^{\#} P<0.05$ versus 2005. AB Alberta; BC British Columbia; MB Manitoba; NB New Brunswick; NL Newfoundland and Labrador; NS Nova Scotia; ON Ontario; PE Prince Edward Island; QC Quebec; NU/NT Nunavut/Northwest Territories; SAGE Survey of Access to GastroEnterology; SK Saskatchewan; YT Yukon

\section{Changing indications for endoscopy}

Descriptive analysis of the proportions of procedures performed for each indication in 2012 and 2008 showed no substantial differences and, in particular, there was no difference between the proportions of screening colonoscopies in the two surveys (21.0\% versus $19.4 \%$, respectively, Table 5).

\section{Wait times according to indication}

Median wait times according to the primary indication for patients included in each of the three surveys are shown in Table 6. Indications were the same in the SAGE 2012 and SAGE 2008 surveys. The PAGE 2005 survey was somewhat different, yielding comparative data for only seven of the indications. There were very small numbers of patients for some indications.

Similar to data reported in 2008, wait times in the present survey were longest for patients undergoing screening colonoscopy. The shortest wait times were, again, reported for those receiving separate or same-day C\&P for indications of 'cancer likely based on imaging or physical exam', 'severe or rapidly progressing dysphagia or odynophagia', 'documented iron deficiency anemia' and 'dyspepsia with alarm symptoms', as well as 'bright red rectal bleeding' in the 2012 survey.

While wait times for several indications remained longer than those reported in 2005 (Table 6), there were few differences compared with 2008. In 2012, significantly longer wait times to consultation were noted for 'confirmation of celiac disease antibody test' and 'chronic viral hepatitis' and to procedure for 'poorly-controlled reflux/ dyspepsia with no alarm symptoms' compared with 2008. However, wait times in 2012 for same-day C\&P were significantly shorter for 'bright red rectal bleeding' and for 'stable dysphagia that is not severe' compared with those reported in 2008.

Wait times for screening colonoscopy were longer if the C\&P occurred on separate days, but were shorter for same-day C\&P in 2012 compared with 2008 (Table 6). Significant increases were noted for time to consultation ( 23 days; 150 days versus 127 days; $\mathrm{P}<0.05)$ and for total wait time ( 78 days; 279 versus 201 days; $\mathrm{P}<0.05$ ) but not for time to procedure ( 22 days; 94 days versus 72 days). However, time to same-day C\&P showed a significant decrease of 48 days (153 days versus 201 days; $\mathrm{P}<0.05$ ).

\section{DISCUSSION}

Periodically assessing wait times for health services is critical in planning for future health care needs in Canada. The SAGE surveys provide data on the delivery of gastroenterology health care and helps organizations, such as the CAG, determine where improvements are needed and resources should be directed. The survey was conducted with minimal burden to
TABLE 5

Proportion of each indication in each of the two most recent SAGE surveys (2012 and 2008)

\begin{tabular}{|c|c|c|}
\hline \multirow[b]{3}{*}{ Indication code } & \multicolumn{2}{|c|}{$\begin{array}{l}\text { Proportion of patients } \\
\text { with each indication, \% }\end{array}$} \\
\hline & \multicolumn{2}{|c|}{ SAGE 2012 SAGE 2008} \\
\hline & $(n=1899)$ & $(n=2263)$ \\
\hline $\begin{array}{l}\text { 1: Severe or rapidly progressing dysphagia or } \\
\text { odynophagia }\end{array}$ & $48(2.5)$ & $44(1.9)$ \\
\hline 2: Stable dysphagia that is not severe & $67(3.5)$ & $65(2.9)$ \\
\hline $\begin{array}{l}\text { 3: Chronic GERD referred for screening } \\
\text { endoscopy }\end{array}$ & $52(2.7)$ & $60(2.7)$ \\
\hline $\begin{array}{l}\text { 4: Poorly controlled reflux/dyspepsia, NO alarm } \\
\text { symptoms }\end{array}$ & $145(7.6)$ & $215(9.5)$ \\
\hline 5: Dyspepsia WITH alarm symptoms & $50(2.6)$ & $67(3.0)$ \\
\hline 6: Confirmation of celiac disease antibody test & $20(1.1)$ & $23(1.0)$ \\
\hline 7. Painless obstructive acute jaundice & $7(0.4)$ & $10(0.4)$ \\
\hline 8: Persistent (>6 months) abnormal liver function tests & $61(3.2)$ & $64(2.8)$ \\
\hline 9: Chronic viral hepatitis & $40(2.1)$ & $38(1.7)$ \\
\hline 10: Chronic abdominal pain & $181(9.5)$ & $205(9.1)$ \\
\hline 11: Clinical features of significant active IBD & $87(4.6)$ & $128(5.7)$ \\
\hline 12: Chronic diarrhea or chronic constipation & $160(8.4)$ & $229(10.1)$ \\
\hline 13: New-onset change in bowel habit & $68(3.6)$ & $109(4.8)$ \\
\hline 14: Bright red rectal bleeding & $181(9.5)$ & $209(9.2)$ \\
\hline 15: Documented iron deficiency anemia & $102(5.4)$ & $132(5.8)$ \\
\hline 16: Fecal occult blood test positive & $65(3.4)$ & 79 (3.5) \\
\hline 17: Screening colonoscopy & $398(21.0)$ & $438(19.4)$ \\
\hline 18: Cancer likely based on imaging or physical exam & $45(2.4)$ & $65(2.9)$ \\
\hline OTHER & $122(6.4)$ & - \\
\hline
\end{tabular}

Surveillance for previous colon cancer or polyps (20)

$56(2.5)$

Weight loss (21)

$8(0.4)$

GERD Gastroesophageal reflux disease; IBD Inflammatory bowel disease; SAGE Survey of Access to GastroEnterology

specialists during a typical work week, thereby providing an up-to-date snapshot of wait times experienced by Canadians needing digestive health care services. The data in the current survey enable evaluation of time trends, in direct comparison with the very similar SAGE 2008 (5) survey and, to a lesser extent, with the PAGE 2005 (3) survey.

The median total wait time reported for all indications in 2012 was unchanged from that reported in 2008, while there was a significant decrease of 23 days in the median time to same-day C\&P. Despite this, wait times continued to be significantly longer than in 2005, and remained well in excess of the 60 -day recommended target wait time for most indications for endoscopy (2). In addition, while the shortest wait times were for indications such as 'cancer likely based on imaging or physical exam' and 'documented iron deficiency anemia', the maximum total wait times and same-day $C \& P$ wait times were in the range of three to six months, whereas the recommended targets are two weeks and two months, respectively.

In addition, the median total wait time for screening colonoscopy further increased from 201 days in 2008 to 279 days in 2012 and continued to exceed the target timeframe of six months (2). However, for screening colonoscopy, there was a decrease in the wait time for same day C\&P from 201 days to 153 days, suggesting that one-half of patients are undergoing the procedure within the recommended six-month target. Analysis of the proportion of screening colonoscopies showed that this indication accounted for approximately $20 \%$ of cases in both the 2012 and 2008 surveys. The reduction in wait times for same day C\&P for screening colonoscopy may be due, in part, to an increase in the use of provincial population-based screening programs that provide financial incentives to ensure individuals undergo colonoscopy in a timely manner. Wait time to endoscopy is particularly important because diagnostic delays were identified as the main contributor to the overall wait time to treatment in a study of patients with colorectal cancer (7). 


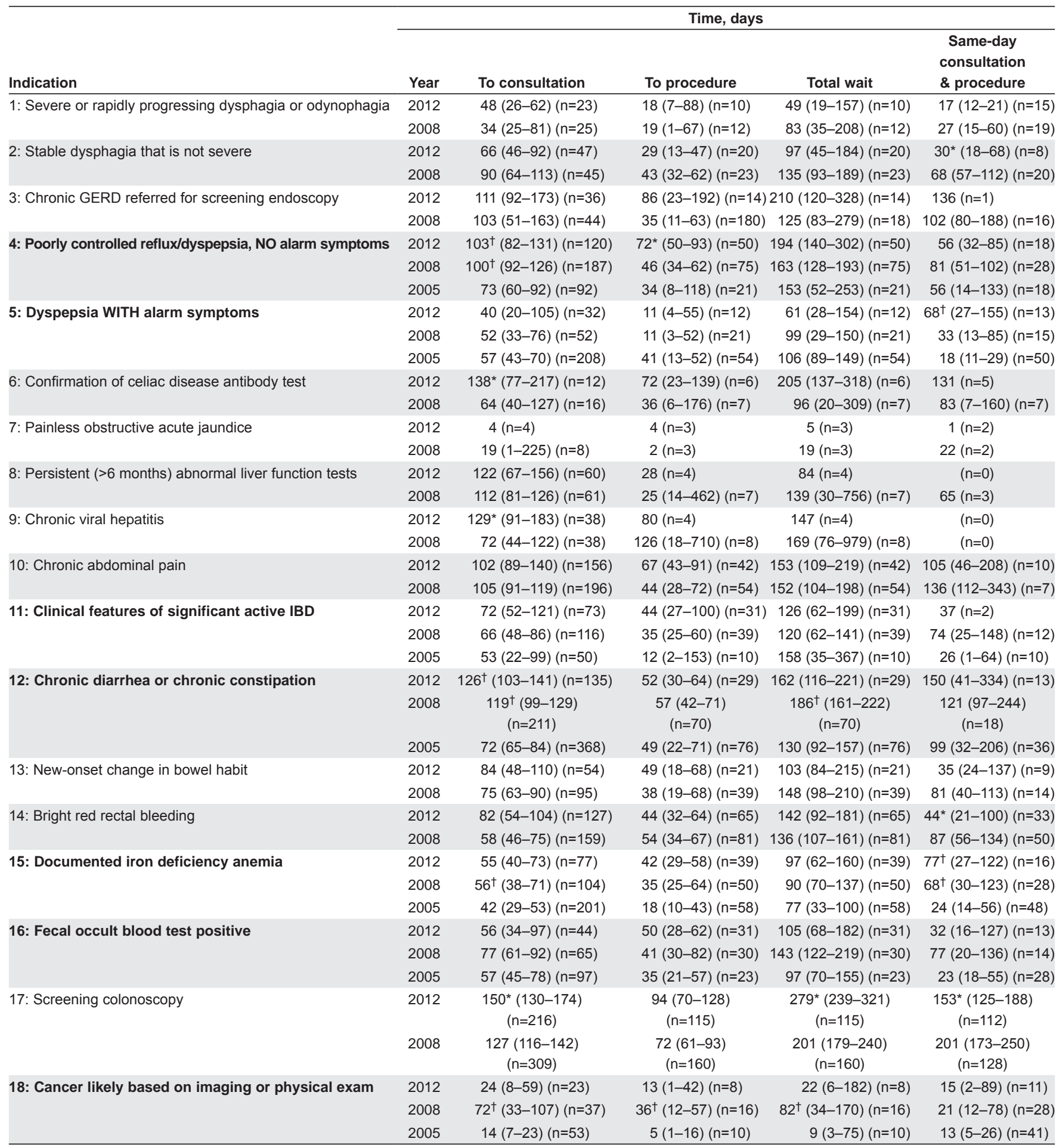

Data presented as median $(95 \% \mathrm{Cl})$. Bolded indications had data available from all three surveys. Note: Lower and upper bound of 95\% Cl only available when sample size >5. *Significantly different from 2008 ( $P<0.05)$; ${ }^{\dagger}$ Significantly different from 2005 ( $\left.P<0.05\right)$. exam Examination; IBD Inflammatory bowel disease; GERD Gastroesophageal reflux disease

While there may have been some reduction in wait times in a few Canadian provinces compared with 2008, these results should be interpreted with caution due to the small numbers of wait times reported in some of the provinces.

The 2011 report by the Fraser Institute detailing wait times for health care access across 12 specialities in Canada (8) showed that patient wait time to specialist consultation was an estimated 67 days - an approximate five-day increase over wait times reported in 2010.
In SAGE 2012 and 2008, the overall median time to consultation was 92 days, which was significantly longer than in PAGE 2005 (69 days). Of the 12 specialities included in the Fraser Institute's report, the median time to specialist consultation for only three specialties plastic surgery, neurosurgery and orthopedic surgery - exceeded the median 92 days to consult reported in SAGE 2012 (8). In the Fraser Institute survey, physicians identified the most important factors contributing to any change in wait times (increase or decrease, $n=897$ ) as 
"availability of operating room time" (59.6\%) and "change in patient load" (36.6\%) (9).

The SAGE surveys are unable to identify reasons why access to nonurgent gastroenterology care continues to fail to meet the recommend targets. Wait times represent a balance between service demands and available resources. Similar to the Fraser Institute survey (8), it is likely that availability of endoscopy facilities is a factor in wait times for endoscopy. Factors, such as a lack of operating rooms, a lack of nurses and specialists, uneven demand or suboptimal regional coordination, may vary substantially among different regions of the country in terms of their impact on patient wait times (1).

The present survey only considers the wait time from the time the patient is referred to the specialist. However, the patient may have already also waited to see their family physician. Once referred, the reduced level of communication between specialists and family practitioners as a result of the shrinking role of the latter within the hospital setting may contribute to lengthy wait times to specialist consultation (1). Online programs promoting increased interactivity between the family practitioner and specialist may facilitate the referral process. Such programs are promising and may prove to be important resources in combating increasing wait times (10-12).

Given that wait times have not improved in the past four years, it is time to consider the roles of other strategies to improve wait times such as adherence to screening and clinical care guidelines, the use of electronic medical records and increased availability of endoscopy resources, whether in hospital or in independent, out-of-hospital endoscopy facilities. In addition, given that wait times for same-day $C \& P$ are markedly less than total wait times (which include waits from referral to consultation and an additional wait from consultation to procedure), it may be worth identifying more patients who could be appropriately referred for same-day C\&P - this would require careful consideration of appropriate indications so that the procedures can be performed safely with patients having the opportunity to provide full, informed consent before the procedure (13).

A recent survey involving 956 patients (14) found that wait times at out-of-hospital clinics were shorter than at in-hospital facilities for asymptomatic patients awaiting screening colonoscopy, but not for symptomatic patients. This strategy of using out-of-hospital facilities may be particularly useful for screening colonoscopy, which accounted for $20 \%$ of indications in the 2012 survey.

Adherence to published guidelines on recommended screening intervals should reduce inappropriate specialist referrals and inappropriate procedures, thereby reducing wait times for patients in whom a procedure is indicated. An analysis of patients $(n=411)$ in the United Kingdom who were waiting for colonoscopy (15) found that $76 \%$ should not have been on the waiting list. Of that $76 \%$, clinical guidelines showed that $42 \%$ were scheduled too early and were not actually due for colonoscopy, and the remaining $34 \%$ had no need for the procedure whatsoever.

In an effort to improve the referral process for patients and reduce wait times, the Northwest Territories has implemented various procedures and tools such as mandatory referral criteria, patient condition prioritization based on specific criteria, a territory-wide electronic medical record system and assessment of referral necessity using telehealth services (1). In addition, a quality assurance program established in Calgary (Alberta) included surveys to monitor the patient experience, endoscopist report cards on colonoscopy performance, as well as tracking and evaluating adverse events and monitoring wait times (16). The use of computerized records and referrals can help ensure timeliness of diagnostic colonoscopy for the evaluation of colorectal cancer diagnoses (17).

As part of the CAG initiative, Quality Program - Endoscopy, newly published consensus recommendations on endoscopy safety and quality indicators are now available. These provide clear and specific evidenced-based guidelines to improve the delivery of endoscopy services in Canada (13).

While colon cancer screening is a major stressor to the system, this does not mean that the strategies or solutions should be directed solely at colorectal cancer screening. Wait times for urgent conditions were too long in 2005 and have changed little; therefore, it is important to prioritize access for all appropriate patients with digestive diseases. This includes appropriate evaluation of patients before referral, communication of the degree of urgency by the referring physician to the specialist (and vice versa), and appropriate availability and management of consultation and endoscopy resources to ensure that patients are seen in a timely manner.

The present survey has several limitations similar to those identified in previous surveys (5). Not all eligible physicians participated in the survey and, therefore, bias may have been introduced by the absence of physicians who were too busy and who may, therefore, have had longer wait times. Although there were approximately $25 \%$ fewer respondents in the present survey compared with the 2008 survey ( $n=173$ versus $n=226)$, it still represents approximately one-third of the gastroenterologists in Canada. In addition, data from other specialists who may also be performing endoscopies, such as surgeons, would not be captured. The data may underestimate wait times because onethird of respondents indicated that they were limiting new referrals, suggesting they may be refusing new consultations if they cannot see them in a timely fashion. The survey also does not account for the effects of other factors such as hospital resources, out-of-hospital endoscopy facilities and other investigations.

\section{SUMMARY}

The present survey provides a snapshot of access to gastroenterology services for Canadians in 2012. Compared with the 2008 survey, wait times have generally not improved and continue to be longer than those reported in 2005. In all three surveys, wait times for many indications exceed consensus conference-recommended targets. Future research should investigate why wait times exceed recommendations so that appropriate strategies can be developed to provide timely patient access to high-quality digestive health services across Canada.

ACKNOWLEDGEMENTS: The authors thank the following individuals for their role in securing specialist participation in SAGE 2012 and/or their active participation in meetings relating to SAGE 2012: David Baron MD, University of Toronto, Toronto, Ontario; Cory Gillis MD, Dalhousie University, Halifax, Nova Scotia, and Memorial University of Newfoundland, St Johns, Newfoundland and Labrador; Joanne Glen RN CGN(C), CSGNA President; James Gray MD, University of British Columbia, Vancouver, British Columbia; Angela Noble MD, Queens University, Kingston, Ontario; Kerri Novak MD, University of Calgary, Calgary, Alberta; Josée Parent MD, McGill University, Montreal, Quebec; Harminder Singh MD, University of Manitoba, Winnipeg, Manitoba; Clarence Wong MD, University of Alberta, Edmonton, Alberta; Krystian Szczesny MD. The authors also thank Pauline Lavigne and Steven Portelance for editorial assistance.

\section{REFERENCES}

1. Wait Time Alliance. Shedding light on Canadians' total wait for care. Report card on wait times in Canada, June 2012. Wait Time Alliance. <www.waittimealliance.ca/media/2012reportcard/ WTA2012-reportcard_e.pdf> (Accessed July 19, 2012).

2. Paterson WG, Depew WT, Pare P, et al. Canadian consensus on medically acceptable wait times for digestive health care. Can J Gastroenterol 2006;20:411-23.

3. Armstrong D, Barkun AN, Chen Y, et al. Access to specialist gastroenterology care in Canada: The Practice Audit in Gastroenterology (PAGE) Wait Times Program. Can J Gastroenterol 2008;22:155-60.

4. Leddin D, Armstrong D, Barkun AN, et al. Access to specialist gastroenterology care in Canada: Comparison of wait times and consensus targets. Can J Gastroenterol 2008;22:161-7.

5. Leddin D, Bridges RJ, Morgan DG, et al. Survey of access to gastroenterology in Canada: The SAGE wait times program. Can J Gastroenterol 2010;24:20-5. 
6. Moayyedi P, Tepper J, Hilsden R, Rabeneck L. International comparisons of manpower in gastroenterology. Am J Gastroenterol 2007;102:478-81.

7. Singh H, De Coster C, Shu E, et al. Wait times from presentation to treatment for colorectal cancer: A population-based study. Can J Gastroenterol 2010;24:33-9.

8. Barua B, Rovere M, Skinner B. Waiting your turn: Wait times for health care in Canada, 2011 report. Fraser Institute. <www.fraserinstitute.org/ uploadedFiles/fraser-ca/Content/research-news/research/publications/ waiting-your-turn-2011.pdf> (Accessed June 3, 2012).

9. Barua B. Why we wait: Physician opinions on factors affecting health care wait times. Fraser Institute <www.fraserinstitute.org/ uploadedFiles/fraser-ca/Content/research-news/research/ publications/why-we-wait.pdf> (Accessed June 3, 2012).

10. Province of Manitoba. New pilot project to further reduce wait times announced for Manitoba. < news.gov.mb.ca/news/index. html?archive $=\&$ \&item $=3334>($ Accessed August 1, 2012) .

11. Solution helps shorten referral wait times. University health system uses referral-automation and decision-support software to reduce wait times for specialty care. Health Manag Technol 2012;33:12-3.

12. MacGregor D, Parker S, MacMillan S, et al. Innovation in managing the referral process at a Canadian pediatric hospital. Healthc Q 2009;12:72-9.
13. Armstrong D, Barkun A, Bridges R, et al. Canadian Association of Gastroenterology consensus guidelines on safety and quality indicators in endoscopy. Can J Gastroenterol 2012;26:17-31.

14. Ivers N, Schwandt M, Hum S, et al. A comparison of hospital and nonhospital colonoscopy: Wait times, fees and guideline adherence to follow-up interval. Can J Gastroenterol 2011;25:78-82.

15. Shoaib A, Hamade A, Zia A, Basnyat PS, Taffinder N. Why wait for a colonoscopy? An easy cure. Colorectal Dis 2006;8:480-3.

16. Hilsden RJ, Rostom A, Dube C, et al. Development and implementation of a comprehensive quality assurance program at a community endoscopy facility. Can J Gastroenterol 2011;25:547-54.

17. Singh $H$, Petersen LA, Daci K, et al. Reducing referral delays in colorectal cancer diagnosis: is it about how you ask? Qual Saf Health Care 2010;19:e27.

18. Statistics Canada. Estimates of population, Canada, provinces and territories. $<w w w 5$.statcan.gc.ca/cansim/a26?lang=eng\& retrLang=en g\&id $=0510005 \&$ paSer $=\&$ pattern $=\& s t B y V a l=2 \& p 1=-$

$1 \& \mathrm{p} 2=31 \&$ tabMode $=$ dataTable\&csid $>$ (Accessed July 12, 2012). 


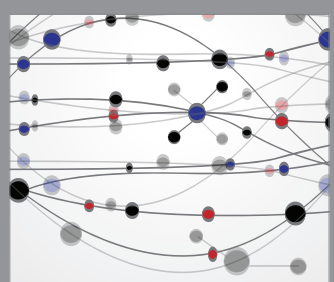

The Scientific World Journal
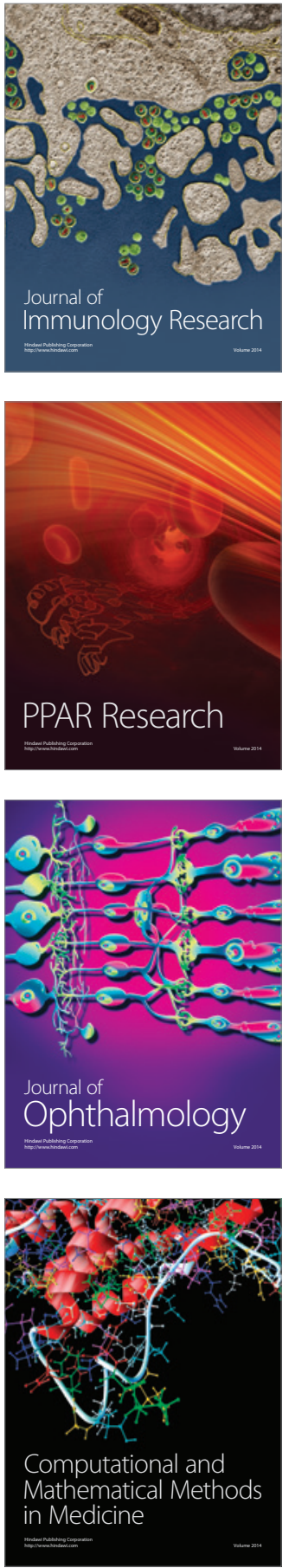

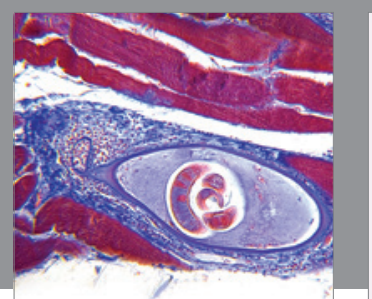

Gastroenterology Research and Practice

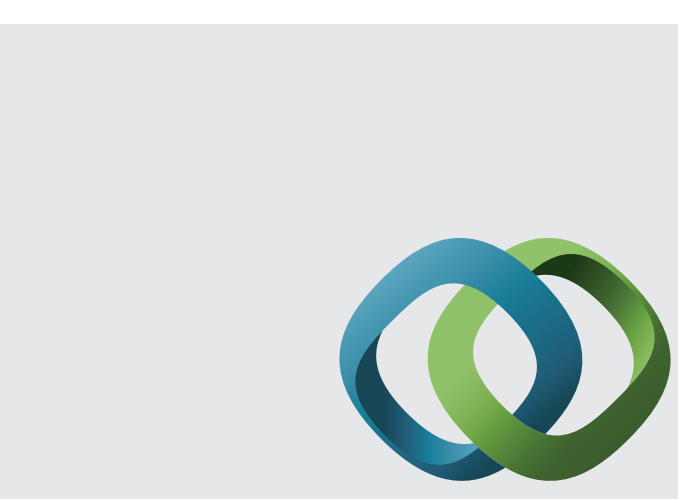

\section{Hindawi}

Submit your manuscripts at

http://www.hindawi.com
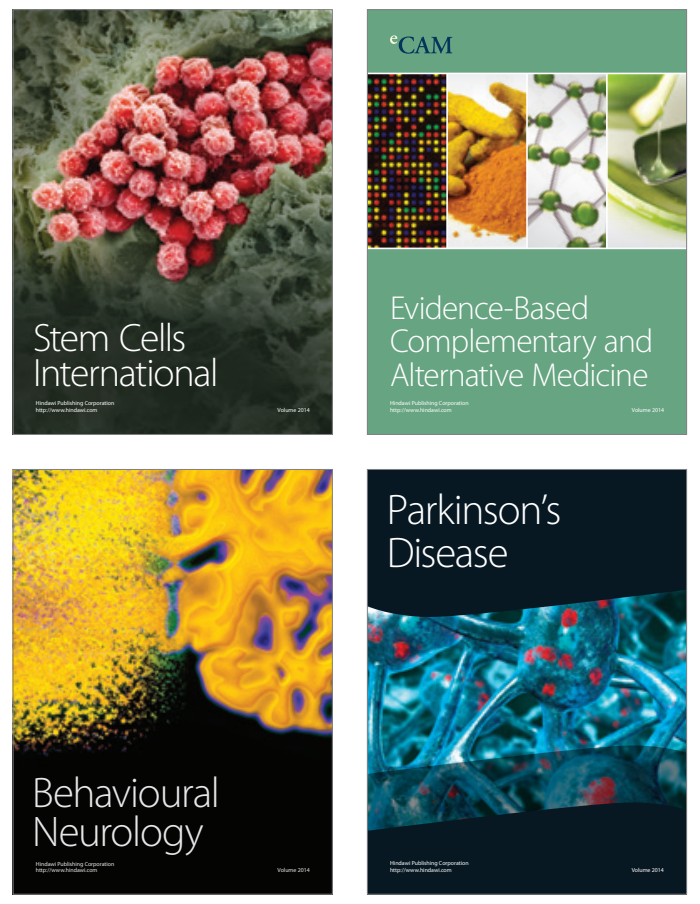
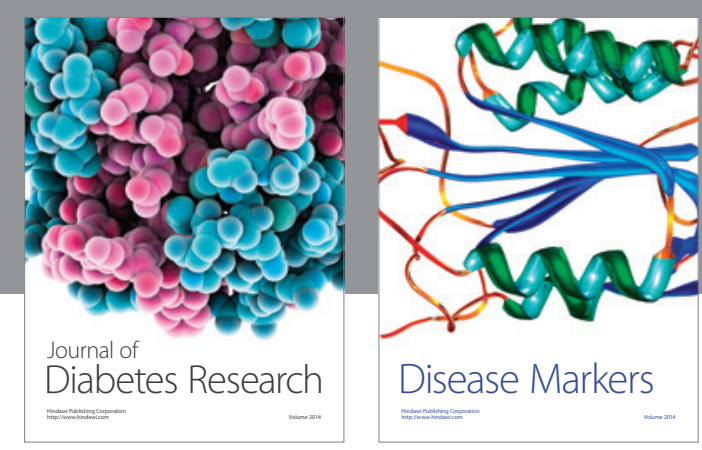

Disease Markers
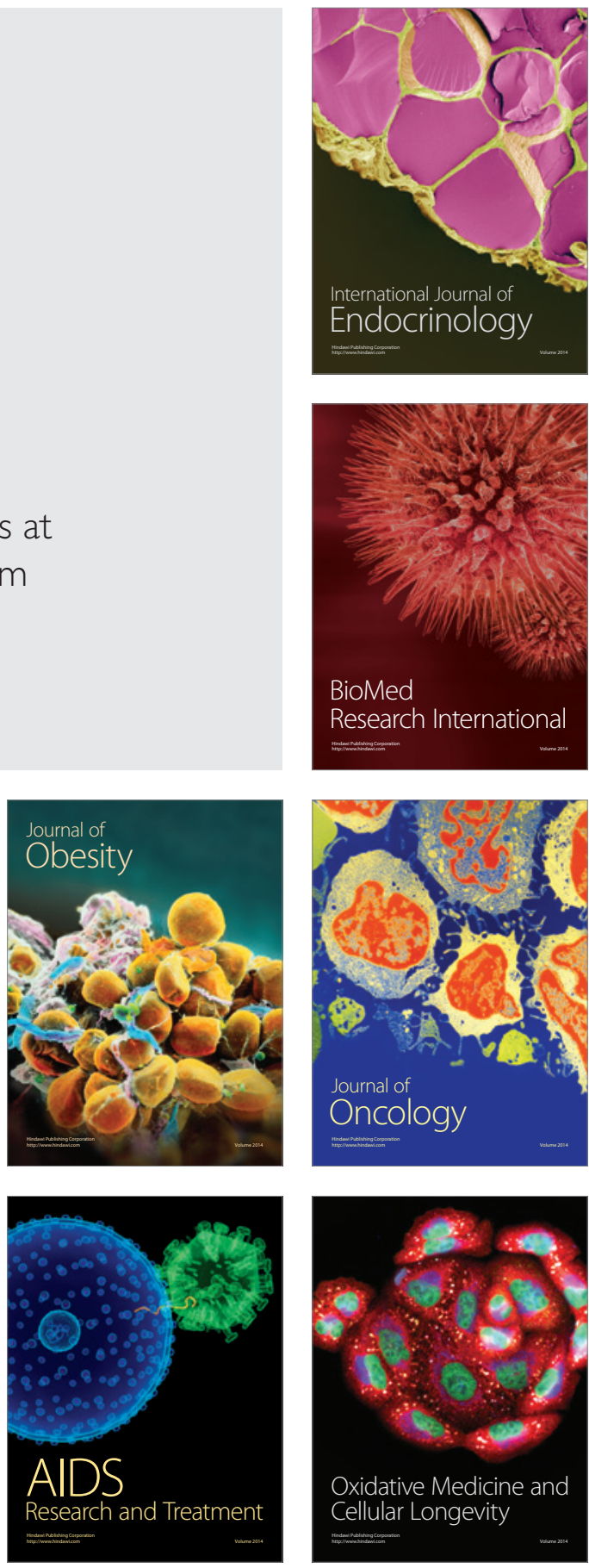